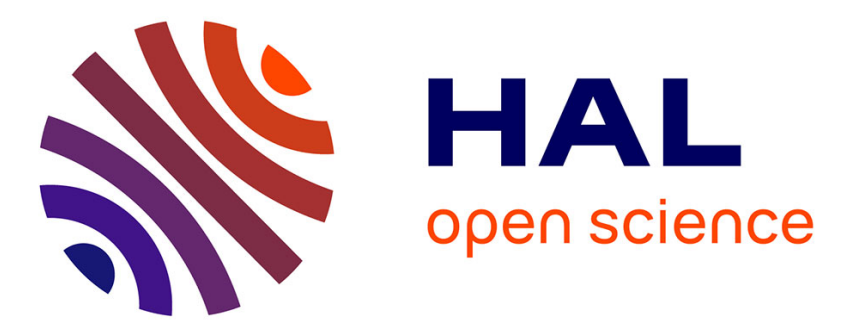

\title{
Rock phosphate-potassium and rock-solubilising bacteria as alternative, sustainable fertilisers
}

\author{
Non Renseigné, Hyo Shim Han, Jae Sung Jung, Kyung Dong Lee
}

\section{To cite this version:}

Non Renseigné, Hyo Shim Han, Jae Sung Jung, Kyung Dong Lee. Rock phosphate-potassium and rocksolubilising bacteria as alternative, sustainable fertilisers. Agronomy for Sustainable Development, 2006, 26 (4), pp.233-240. hal-00886324

\section{HAL Id: hal-00886324 \\ https://hal.science/hal-00886324}

Submitted on 1 Jan 2006

HAL is a multi-disciplinary open access archive for the deposit and dissemination of scientific research documents, whether they are published or not. The documents may come from teaching and research institutions in France or abroad, or from public or private research centers.
L'archive ouverte pluridisciplinaire HAL, est destinée au dépôt et à la diffusion de documents scientifiques de niveau recherche, publiés ou non, émanant des établissements d'enseignement et de recherche français ou étrangers, des laboratoires publics ou privés. 


\title{
Rock phosphate-potassium and rock-solubilising bacteria as alternative, sustainable fertilisers
}

\author{
SUPANJANI ${ }^{\mathrm{a}}$, Hyo Shim HAN ${ }^{\mathrm{b}}$, Jae Sung JUNG ${ }^{\mathrm{b}}$, Kyung Dong LEE ${ }^{\mathrm{a}, \mathrm{c} *}$ \\ a Department of Plant Science, McGill University, Macdonald Campus, 21111 Lakeshore Road, Ste-Anne-de-Bellevue, QC, H9X 3V9, Canada \\ ${ }^{\mathrm{b}}$ Department of Biology, Sunchon National University, Suncheon, Jeonnam 540-742, Korea \\ ${ }^{\mathrm{c}}$ Department of Oriental Medicine Materials, Dongshin University, 252 Daeho-dong, Naju, Jeonnam 520-714, Korea
}

(Accepted 9 August 2006)

\begin{abstract}
Classical, soluble fertilisers create environmental and economic problems. As an alternative, we studied the direct applications of phosphate rock and potassium rock in conjunction with phosphate-solubilising bacteria and potassium-solubilising bacteria for cultivation of hot pepper Capsicum annuum L. Our findings show that integration of $\mathrm{P}$ and $\mathrm{K}$ rocks with inoculation of $\mathrm{P}$ - and K-solubilising bacteria increased $\mathrm{P}$ availability from 12 to $21 \%$ and $\mathrm{K}$ availability from 13 to $15 \%$ in the soil as compared with control, and subsequently improved nutrient $(\mathrm{N}, \mathrm{P}$ and $\mathrm{K})$ uptake to the plant. This integration also increased plant photosynthesis by $16 \%$ and leaf area by $35 \%$ as compared with control plants. Similarly, biomass harvest and fruit yield of the treated plants were $23 \%$ and $30 \%$, respectively, higher as compared with control. Overall, we found that the treatment with P and K rocks and PK-solubilising bacterial strains and the treatment with classical, soluble fertiliser have a similar effectiveness. Therefore, direct application of $\mathrm{P}$ and $\mathrm{K}$ rocks and solubilising bacteria is a promising, sustainable alternative to the use of classical fertilisers.
\end{abstract}

hot pepper / phosphate-solubilising bacteria / potassium-solubilising bacteria / mineral uptake / soil availability / acid phosphatase activity

\section{INTRODUCTION}

Modern crop production depends heavily upon industrial fertilisers that are expensive, and also cause pollution and farmland degradation (Brown, 2000). The use of plant growth-promoting rhizobacteria (PGPR), including phosphate- and potassium-solubilising bacteria as biofertilisers, has been suggested as a sustainable solution to improve plant nutrient and production (Vessey, 2003). Large areas of cultivated land in Korea and China are deficient in phosphorus and potassium nutrients (Xie, 1998), and soluble industrial fertilisers, such as triple superphosphate and diammonium phosphate, are commonly applied to improve plant growth and replace minerals removed during harvest. When added to soils, soluble phosphate fertilisers are easily converted into insoluble complexes with calcium carbonate, aluminum and iron oxides, and crystalline and amorphous aluminum silicate (Sample et al., 1980). Consequently, to achieve optimum crop yields, soluble phosphate fertiliser has to be applied at rates which cause unmanageable excess of phosphate application and create environmental and economic problems (Brady, 1990). On the other hand, $\mathrm{K}$ deficiencies are a problem because it decreases easily in soils due to crop uptake, runoff, leaching and soil ero- sion (Sheng and Huang, 2002). Direct application of phosphate and potassium rocks may be more useful agronomically and environmentally more sustainable than industrial soluble $\mathrm{P}$ and K fertilisers (Rajan et al., 1996).

Phosphate and potassium rocks are a cheaper source of $P$ and $\mathrm{K}$; however, they are less readily available to plants because the minerals are released slowly and their use as a fertiliser often does not increase yield. The potential of phosphate-solubilising bacteria, such as Bacillus megaterium var. phosphaticum, for increasing crop yields, to convert insoluble phosphate in rocks into soluble forms available for plant growth, has been reported (Nahas et al., 1990; Bojinova et al., 1997; Schilling et al., 1998). This conversion is through acidification, chelation and exchange reactions (Gerke, 1992) and produces strong organic acids in the periplasm (Alexander, 1977), which have become indicators for routine isolation and selection of phosphate-solubilising bacteria (e.g. Illmer et al., 1995). KSB, such as Bacillus mucilaginosus, are able to solubilise potassium mineral powder, such as micas, illite and orthoclases, and increase $\mathrm{K}$ availability in soils and mineral content in plants (Friedrich et al., 1991; Ullman et al., 1996; Sheng et al., 2002).

Integrated application of phosphate and potassium rocks with the co-inoculation of bacteria that solubilise those fertilisers

* Corresponding author: leekd1@ hotmail.com 
may provide a faster and more continuous supply of $\mathrm{P}$ and $\mathrm{K}$ for optimal plant growth. However, little is known about the combined effects of rock materials and co-inoculation of $\mathrm{P}$ - and $\mathrm{K}$-solubilising bacteria on mineral availability in soils, mineral content and growth of hot pepper. The present work reports the results of field experiments to evaluate the effects of soil fertilisation with phosphate and potassium rocks in combination with the co-inoculation of PK-solubilising bacteria on the improvement of $\mathrm{P}$ and $\mathrm{K}$ uptake and the growth and production of hot pepper plants.

\section{MATERIALS AND METHODS}

\subsection{Soil and bacteria materials}

Field experiments were conducted to determine the effects of $\mathrm{P}$ - and K-solubilising bacteria on growth of hot pepper ( $\mathrm{Cap}$ sicum annuum L.) in the two growing seasons of 2001 and 2002 in Chinju, Kyungnam province, Korea ( $\left.35^{\circ} 12^{\prime} \mathrm{N}, 128^{\circ} 07^{\prime} \mathrm{E}\right)$. The soil contained low phosphate and potassium and was characterised as Aquepts Series, Typic Endoaquepts (Inceptisols) with the chemical properties: $\mathrm{pH}(1: 5 \mathrm{w} / \mathrm{v}$ water) 5.8 , organic matter $19.5 \mathrm{~g} \mathrm{~kg}^{-1}$, total $\mathrm{N} 2.1 \mathrm{~g} \mathrm{~kg}^{-1}$, available P $9.8 \mathrm{mg} \mathrm{kg}^{-1}$ and available $\mathrm{K} 47.9 \mathrm{mg} \mathrm{kg}^{-1}\left(1 \mathrm{M} \mathrm{NH}_{4}-\mathrm{OAc}\right)$. The soluble fertiliser was N-P-K=0-8.4-15.8 (Namhae Co., Korea). Phosphate rock powder $(<1 \mathrm{~mm}$, from China) contains $15 \%$ total $\mathrm{P}$ and potassium rock powder (Illite powder, $<1 \mathrm{~mm}$, from Korea) contains $4.0 \% \mathrm{~K}$. We used two strains of plant growth-promoting rhizobacteria (PGPR) in these experiments. For P-solubilising bacteria, Bacillus megaterium var. phosphaticum was isolated from a plastic film house area in Korea by using the medium $(1.0 \%$ polypeptone, $0.5 \%$ beef extract, $0.2 \% \mathrm{NaCl}$, $0.05 \%$ yeast extract). This strain was identified by Han et al. (2006) and was proven in its efficiency to solubilise many phosphatic compounds, such as aluminum phosphate and rock phosphate (Sundara et al., 2002). For K-solubilising bacteria, we used Bacillus mucilaginosus strain KCTC3870 (Korean Collection of Type Cultures).

\subsection{Bacterial culture and inoculant preparation}

PK-solubilising bacteria were cultured in Tryptone Yeast medium (Vincent, 1970) and sucrose-minimal salts medium (Sheng et al., 2002), respectively, and incubated on an orbital shaker at $150 \mathrm{rpm}$ for $48 \mathrm{~h}$ at $27^{\circ} \mathrm{C}$. The cells in cultured bacterial broth were collected by centrifugation at $2822 \times g$ for 15 min at $4{ }^{\circ} \mathrm{C}$ and washed with sterilised tap water. The pelleted cells was resuspended in sterilised tap water and then the cells were adjusted to about $10^{8}$ cells $\mathrm{mL}^{-1}$, based on optical density $\mathrm{OD}_{620}=0.08$ (Bhuvaneswari et al., 1980).

\subsection{Field conditions}

The experiments were established with 11 treatments, consisting of the combinations of $100 \mathrm{~kg} \mathrm{ha}^{-1}$ soluble fertiliser, $56 \mathrm{~kg} \mathrm{ha}^{-1} \mathrm{P}$ rock, $395 \mathrm{~kg} \mathrm{ha}^{-1} \mathrm{~K}$ rock, $\mathrm{P}$-solubilising bacteria, PK-solubilising bacteria, K-solubilising bacteria, and control without rock fertiliser materials or bacterial inoculation (see Tab. I). Plots were arranged in a randomised complete block design with four replications of each treatment. Each plot was $3.0 \mathrm{~m}$ by $5.0 \mathrm{~m}$, consisting of five rows of plants, with a spacing of $1.0 \mathrm{~m}$ between rows and $30 \mathrm{~cm}$ within the rows. The space between adjacent blocks was $2.0 \mathrm{~m}$ and the space between plots was $1.0 \mathrm{~m}$.

Rock materials were mixed thoroughly with the soil in each plot to ensure the solubilisation effect of the rock nutrients by the inoculated bacteria. The fertiliser materials were spread evenly on the field 3 days before seedlings were transplanted into the field. The inoculants were applied evenly into the open row at $3-\mathrm{cm}$ depth using a $50-\mathrm{mL}$ syringe, at a rate of $10 \mathrm{~mL}$ of inoculum per seedling, before the seedlings were transplanted into the field, and before the surface was covered with black-coloured plastic film.

Seedlings were prepared by surface-sterilising hot pepper seeds with $2 \%$ sodium hypochlorite for $3 \mathrm{~min}$ and then rinsing 5 times with distilled water. The seeds were sown on February 27 each year and grown in sterilised vermiculite in trays in a greenhouse. Half-strength Hoagland's solution was used for irrigation (Hoagland and Arnon, 1950). At 9 weeks after sowing, hot pepper seedlings were transplanted into the field on May 7, 2001 and on May 6, 2002.

Plots were hand-weeded as needed. The photosynthesis of plants was measured by using a Li-Cor 6400 (Li-Cor Inc, Lincoln, Nebraska, USA) at 10 and 20 weeks after transplanting. All plants were harvested 20 weeks, on September 30, 2001 and on October 1, 2002, after transplanting, and the redcoloured fruit was harvested every week during the experiment. The growth and yield characteristics were investigated by using the methods released by Rural Development Administration, Korea (RDA, 1995).

\subsection{Mineral content}

To analyse mineral elements, soil samples were collected before and after the experiments and air-dried for chemical analysis. Soil samples were sieved $(<2 \mathrm{~mm}$ screen) and analysed for the following: $\mathrm{pH}(1: 5 \mathrm{w} / \mathrm{v}$, water extraction), organic matter content (Wakley and Black method; Allison, 1965), available $\mathrm{P}$ content (Lancast method; RDA, 1988: $5 \mathrm{~g}$ of soil was extracted with $20 \mathrm{~mL}$ of $0.33 \mathrm{M} \mathrm{CH}_{3} \mathrm{CHOOH}, 0.15 \mathrm{M}$ lactic acid, $0.03 \mathrm{M} \mathrm{NH}_{4} \mathrm{~F}, 0.05 \mathrm{M}\left(\mathrm{NH}_{4}\right)_{2} \mathrm{SO}_{4}$, and $0.2 \mathrm{M} \mathrm{NaOH}$ at $\mathrm{pH} 4.25)$ and contents of exchangeable or available $\mathrm{K}^{+}(1 \mathrm{M}$ $\mathrm{NH}_{4}$-OAc pH 7, AA, Shimazu 660; Richards and Bates, 1989). Available $\mathrm{P}$ and $\mathrm{K}$ contents were measured twice, 10 and 20 weeks after transplanting. Shoot, root and fruit tissues were separated after harvesting and air-dried at $70{ }^{\circ} \mathrm{C}$ for 5 days. The dried materials were then ground and digested in $\mathrm{H}_{2} \mathrm{SO}_{4}$ for determination of total $\mathrm{N}$ (Kjeldahl method; Bremner, 1965) or in a ternary solution $\left(\mathrm{HNO}_{3}: \mathrm{H}_{2} \mathrm{SO}_{4}: \mathrm{HClO}_{4}=10: 1: 4\right.$ with volume) for the determination of $\mathrm{P}$ and $\mathrm{K}$.

\subsection{Acid phosphatase activity}

Acid phosphatase activity was determined by using a modified assay of Tabatabai (1982). One gram of sieved rhizosphere soil ( $<2 \mathrm{~mm}$ screen) was placed into a $50-\mathrm{mL}$ Erlenmeyer flask, and then a solution containing $0.2 \mathrm{~mL}$ toluene and $5 \mathrm{~mL}$ universal buffer of $\mathrm{pH} 6.5$ was added. The acid 
Table I. Effects of PK rocks and PK-solubilising bacteria on plant growth and yield of hot pepper in the 2001 and 2002 growing seasons. $\mathrm{LSD}_{0.05}=$ least significant difference at probability level of 5\%; $\mathrm{SF}=$ soluble fertiliser; $\mathrm{RP}=$ rock phosphate powder; $\mathrm{RK}=$ rock potassium powder; $\mathrm{PSB}=$ phosphate-solubilising bacteria; $\mathrm{KSB}=$ potassium-solubilising bacteria.

\begin{tabular}{|c|c|c|c|c|c|c|c|c|}
\hline \multirow[t]{3}{*}{ Treatment } & \multirow[t]{3}{*}{ Shoot } & \multirow{3}{*}{\multicolumn{2}{|c|}{$\begin{array}{ll}\text { Root } & \text { Fruit } \\
\left.\text { g plant }^{-1}, \text { dry base }\right)\end{array}$}} & \multirow[t]{3}{*}{ Total } & \multicolumn{4}{|c|}{ Yield } \\
\hline & & & & & Shoot & Root & Fruit & Total \\
\hline & & & & & \multicolumn{4}{|c|}{$\left(\mathrm{t} \mathrm{ha}^{-1}\right.$, dry base $)$} \\
\hline \multicolumn{9}{|l|}{2001} \\
\hline Control & 160.0 & 22.4 & 45.3 & 227.7 & 5.33 & 0.75 & 1.51 & 7.59 \\
\hline SF & 201.4 & 27.3 & 61.1 & 289.8 & 6.71 & 0.91 & 2.04 & 9.66 \\
\hline RP & 179.2 & 24.8 & 51.7 & 255.7 & 5.97 & 0.83 & 1.72 & 8.52 \\
\hline RK & 167.9 & 22.6 & 49.3 & 239.8 & 5.60 & 0.75 & 1.64 & 7.99 \\
\hline $\mathrm{RP}+\mathrm{RK}$ & 181.5 & 25.9 & 53.7 & 261.1 & 6.05 & 0.86 & 1.79 & 8.70 \\
\hline PSB & 163.6 & 23.2 & 46.3 & 233.1 & 5.45 & 0.77 & 1.54 & 7.77 \\
\hline KSB & 159.9 & 21.5 & 45.8 & 227.2 & 5.33 & 0.72 & 1.53 & 7.57 \\
\hline $\mathrm{PSB}+\mathrm{KSB}$ & 170.2 & 24.2 & 47.1 & 241.5 & 5.67 & 0.81 & 1.57 & 8.05 \\
\hline $\mathrm{RP}+\mathrm{PSB}$ & 190.5 & 26.1 & 57.4 & 274.0 & 6.35 & 0.87 & 1.91 & 9.13 \\
\hline $\mathrm{RK}+\mathrm{KSB}$ & 181.7 & 24.8 & 54.9 & 261.4 & 6.06 & 0.83 & 1.83 & 8.71 \\
\hline $\mathrm{RP}+\mathrm{RK}+\mathrm{PSB}+\mathrm{KSB}$ & 195.2 & 26.5 & 59.2 & 280.9 & 6.51 & 0.88 & 1.97 & 9.36 \\
\hline $\mathrm{LSD}_{0.05}$ & 20.6 & 3.9 & 8.1 & 30.0 & 0.61 & 0.10 & 0.21 & 1.01 \\
\hline \multicolumn{9}{|l|}{2002} \\
\hline Control & 166.1 & 23.3 & 46.4 & 235.8 & 5.54 & 0.78 & 1.55 & 7.86 \\
\hline SF & 210.1 & 28.5 & 62.2 & 300.8 & 7.00 & 0.95 & 2.07 & 10.03 \\
\hline $\mathrm{RP}$ & 185.2 & 25.1 & 52.5 & 262.8 & 6.17 & 0.84 & 1.75 & 8.76 \\
\hline RK & 171.3 & 24.5 & 50.2 & 246.0 & 5.71 & 0.82 & 1.67 & 8.20 \\
\hline $\mathrm{RP}+\mathrm{RK}$ & 187.7 & 26.1 & 53.9 & 267.7 & 6.26 & 0.87 & 1.80 & 8.92 \\
\hline PSB & 173.2 & 23.8 & 48.7 & 245.7 & 5.77 & 0.79 & 1.62 & 8.19 \\
\hline KSB & 162.3 & 22.4 & 44.9 & 229.6 & 5.41 & 0.75 & 1.50 & 7.65 \\
\hline $\mathrm{PSB}+\mathrm{KSB}$ & 178.5 & 24.7 & 49.2 & 252.4 & 5.95 & 0.82 & 1.64 & 8.41 \\
\hline $\mathrm{RP}+\mathrm{PSB}$ & 199.6 & 26.7 & 58.4 & 284.7 & 6.65 & 0.89 & 1.95 & 9.49 \\
\hline $\mathrm{RK}+\mathrm{KSB}$ & 190.1 & 24.8 & 54.6 & 269.5 & 6.34 & 0.83 & 1.82 & 8.98 \\
\hline $\mathrm{RP}+\mathrm{RK}+\mathrm{PSB}+\mathrm{KSB}$ & 203.4 & 28.6 & 60.3 & 292.3 & 6.78 & 0.95 & 2.01 & 9.74 \\
\hline $\mathrm{LSD}_{0.05}$ & 22.3 & 3.4 & 8.5 & 26.5 & 0.62 & 0.08 & 0.25 & 0.98 \\
\hline
\end{tabular}

phosphatase activity assay was started by adding $1 \mathrm{~mL}$ solution of $0.25 \mathrm{mM}$-nitrophenyl phosphate and vortexing the mixture. After incubation at $37^{\circ} \mathrm{C}$ for $1 \mathrm{~h}$, the reaction was terminated by adding $1.0 \mathrm{~mL} 0.5 \mathrm{M} \mathrm{CaCl}_{2}$ and $4 \mathrm{~mL} 0.5 \mathrm{M} \mathrm{NaOH}$. The assay mixtures were filtered through Whatman No. 2 filter papers. Acid phosphatase activity was determined using a spectrophotometer (Shimaszu, UV-Vis 1600, Japan) at $420 \mathrm{~nm}$.

\subsection{Statistical analysis}

All data were analysed statistically by analysis of variance using CoStat software (CoHort Software, Monterey, USA). The comparisons of treatment means were conducted using an ANOVA protected least significant difference (LSD) test at $P<$ 0.05 .

\section{RESULTS AND DISCUSSION}

\subsection{Plant growth and yield}

Two-year field experiments were conducted to evaluate the suitability of $\mathrm{P}$ and $\mathrm{K}$ rock application in combination with inoculation of $\mathrm{P}$ - and $\mathrm{K}$-solubilising bacteria as a sustainable alternative to the use of conventional fertiliser for hot pepper production. The results from both the 2001 and 2002 experiments demonstrated that some treatments consistently increased shoot, root, fruit yield and total dry weight production of hot pepper per hectare as compared with the control (Tab. I) The increases were $8-35 \%$ over the control $(P<0.05)$ and were also consistent in the treatment order of:

(1) Soluble fertiliser: $21-35 \%$ increases, 


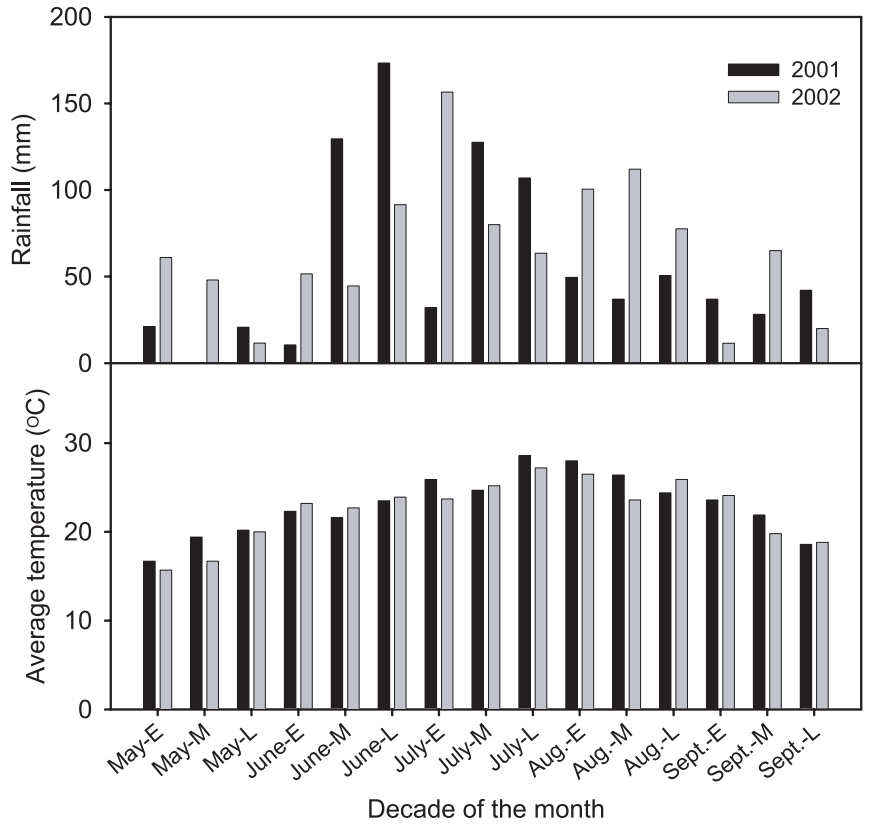

Figure 1. Rainfall and temperature during the 2000 and 2001 growing seasons.

(2) PK rocks and PK-solubilising bacteria: 17-30\% increases,

(3) P rock and P-solubilising bacteria: 14-26\% increases, and

(4) K rock and K-solubilising bacteria: $12-19 \%$ increases.

Although the differences among these treatments were not significant (Tab. I). Although there was no difference among the mentioned treatments in total dry matter yield in 2001, application of PK rocks resulted in a lower increase in fruit yield as compared with the use of soluble fertiliser in 2001, and also of fruit and of total dry matter yield in 2002. The combination of $\mathrm{K}$ rock and $\mathrm{K}$-solubilising bacteria during both 2001 and 2002 increased dry weights of fruit and total plants per hectare $(P<0.05)$, on average 19 and $14 \%$ over $1.53 \mathrm{t}_{\text {fruit }} \mathrm{ha}^{-1}$ and 7.73 t total plant ha $^{-1}$ in the control, respectively, which are slightly higher than those increased by RK rock treatment ( 8 and 9\%, respectively) (Tab. I). Soluble fertiliser and the complete integration of $\mathrm{PK}$ rocks and PK-solubilising bacteria increased fruit yield $(P<0.05)$ by 35 and $30 \%$, respectively, compared with the control, but were similar to each other. Rainfall and temperature were similar in both the 2001 and 2002 growing seasons (Fig. 1), and were probably adequate for hot pepper growth: they did not cause a significant variation in plant growth.

Soluble fertiliser, the combination of $\mathrm{P}$ rock powder and $\mathrm{P}-$ solubilising bacteria, and the complete combination of PK rocks and PK-solubilising bacteria consistently increased leaf area $(P<0.05)$ by 34,26 and $36 \%$, respectively, over $2239 \mathrm{~cm}^{2}$ plant $^{-1}$ in the control plants in 2001 and 2002 on average (Fig. 2). Applications of PK rocks or the combination of $\mathrm{P}$ rock powder and P-solubilising bacteria also increased hot pepper leaf area compared with the control $(P<0.05)$, whereas the application of RK was not significantly different from the control. No significantly larger leaf area was found following inoc-

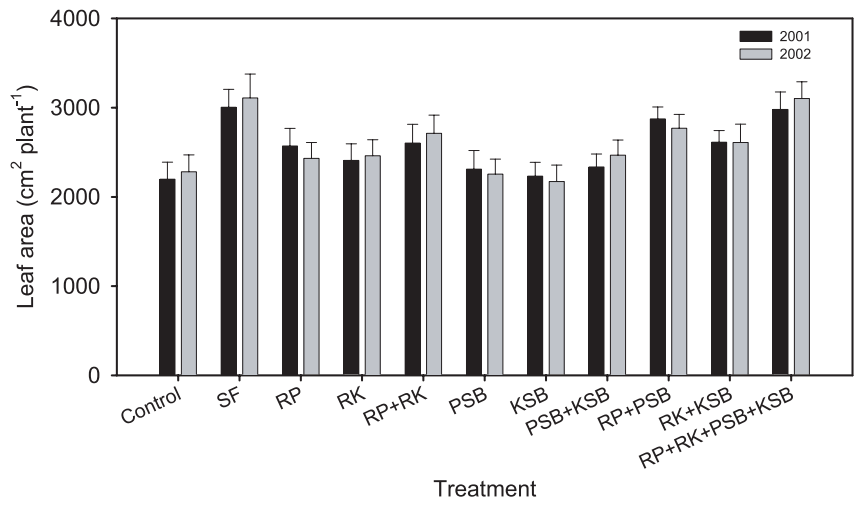

Figure 2. Effects of PK rock powder and PK-solubilising bacterial strains on leaf area of hot pepper during the two growing seasons of 2001 and 2002. Means are shown \pm standard error $(n=4) . S F=$ soluble fertiliser; $\mathrm{RP}=$ rock phosphate powder; $\mathrm{RK}=$ rock potassium powder; PSB = phosphate-solubilising bacteria; KSB = potassiumsolubilising bacteria. The complete combination of PK rocks and PKsolubilising bacteria resulted in a similar leaf area to the application of soluble fertiliser; both of them produced a $39.1 \%$ and $35.8 \%$ larger leaf area, respectively, as compared with control.

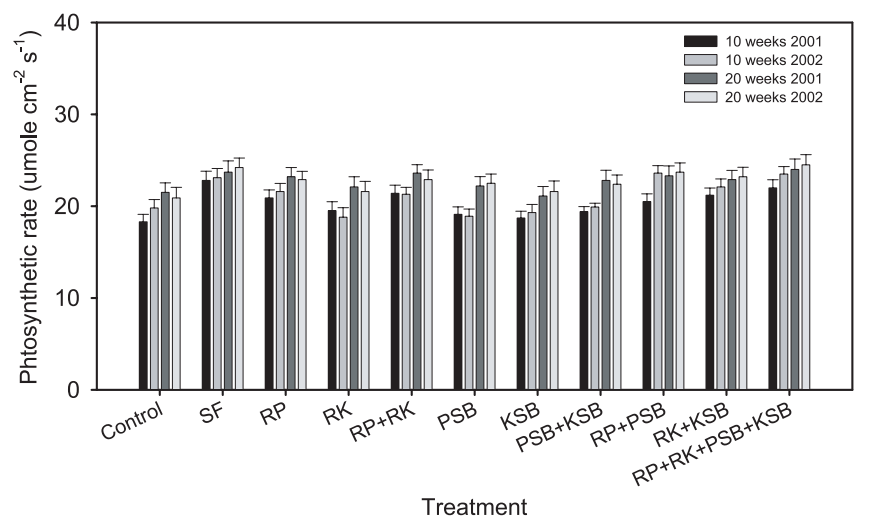

Figure 3. Effects of PK rock powder and PK-solubilising bacterial strains on photosynthetic rate of hot pepper during the two growing seasons of 2001 and 2002. Means are shown \pm standard error $(n=4)$. $\mathrm{SF}=$ soluble fertiliser $\mathrm{RP}=$ rock phosphate powder; $\mathrm{RK}=$ rock potassium powder; $\mathrm{PSB}=$ phosphate-solubilising bacteria; $\mathrm{KSB}=$ potassium-solubilising bacteria. The combination of PK rocks and PKsolubilising bacterial strains, and combination of $\mathrm{P}$ rocks and P-solubilising bacteria produced a similar photosynthetic rate to the application of soluble fertiliser; both of them resulted in a $16.8 \%$ and $16.7 \%$ higher photosynthetic rate, respectively, as compared with control.

ulation of P-solubilising bacteria and K-solubilising bacteria, whether applied singly or combined together.

Leaf photosynthetic activities demonstrated similar trends to those of leaf area in response to applications of rock materials and inoculation of PGPR (Fig. 3). There were higher photosynthetic rates when measured at 20 weeks as compared with those at 10 weeks, although there was no difference with respect to leaf photosynthetic activity between the 2001 and 2002 growing seasons.

Our experiments demonstrated that the co-inoculation of rock materials with Bacillus strains, $\mathrm{P}$-solubilising bacteria and 
Table II. Effects of PK rocks and PK-solubilising bacteria on available P and K in rhizosphere soil, which contained low $\mathrm{P}$ and $\mathrm{K}$ nutrients, of hot pepper grown at 10 and 20 weeks after transplanting during the two growing seasons of 2001 and 2002 . LSD $0.05=$ least significant difference at probability level of $5 \% ; \mathrm{SF}=$ soluble fertiliser; $\mathrm{RP}=$ rock phosphate powder; $\mathrm{RK}=$ rock potassium powder; $\mathrm{PSB}=$ phosphate-solubilising bacteria; $\mathrm{KSB}=$ potassium-solubilising bacteria.

\begin{tabular}{|c|c|c|c|c|c|c|c|c|}
\hline \multirow[t]{4}{*}{ Treatments } & \multicolumn{4}{|c|}{2001} & \multicolumn{4}{|c|}{2002} \\
\hline & \multicolumn{2}{|c|}{10 weeks } & \multicolumn{2}{|c|}{20 weeks } & \multicolumn{2}{|c|}{10 weeks } & \multicolumn{2}{|c|}{20 weeks } \\
\hline & $\mathrm{P}$ & $\mathrm{K}$ & $\mathrm{P}$ & $\mathrm{K}$ & $\mathrm{P}$ & $\mathrm{K}$ & $\mathrm{P}$ & $\mathrm{K}$ \\
\hline & \multicolumn{4}{|c|}{$\left(\mathrm{mg} \mathrm{kg}^{-1}\right.$ soil $)$} & \multicolumn{4}{|c|}{$\left(\mathrm{mg} \mathrm{kg}^{-1}\right.$ soil $)$} \\
\hline Control & 12.3 & 44.2 & 10.9 & 34.3 & 13.2 & 45.6 & 10.3 & 37.4 \\
\hline SF & 15.5 & 53.7 & 12.3 & 39.2 & 16.3 & 53.4 & 12.0 & 43.3 \\
\hline RP & 14.0 & 45.5 & 11.7 & 33.4 & 14.1 & 46.1 & 11.2 & 37.5 \\
\hline RK & 13.2 & 47.3 & 11.1 & 36.8 & 13.9 & 48.7 & 11.1 & 40.9 \\
\hline $\mathrm{RP}+\mathrm{RK}$ & 14.1 & 48.2 & 11.9 & 38.4 & 14.6 & 49.4 & 11.3 & 40.2 \\
\hline PSB & 12.6 & 42.6 & 9.6 & 31.6 & 13.3 & 44.4 & 10.9 & 34.7 \\
\hline KSB & 12.5 & 44.1 & 9.8 & 31.1 & 12.9 & 45.9 & 10.7 & 36.7 \\
\hline $\mathrm{PSB}+\mathrm{KSB}$ & 12.9 & 45.3 & 10.4 & 31.8 & 13.7 & 45.7 & 10.8 & 35.8 \\
\hline $\mathrm{RP}+\mathrm{PSB}$ & 14.5 & 45.5 & 12.1 & 33.9 & 15.2 & 44.9 & 11.6 & 37.5 \\
\hline $\mathrm{RK}+\mathrm{KSB}$ & 13.9 & 49.7 & 11.0 & 37.5 & 13.3 & 52.1 & 10.8 & 41.6 \\
\hline $\mathrm{RP}+\mathrm{RK}+\mathrm{PSB}+\mathrm{KSB}$ & 15.0 & 50.2 & 12.6 & 38.9 & 15.5 & 53.6 & 11.6 & 43.0 \\
\hline $\mathrm{LSD}_{0.05}$ & 1.7 & 2.5 & 1.0 & 2.2 & 1.2 & 2.7 & 1.3 & 2.6 \\
\hline
\end{tabular}

K-solubilising bacteria enhanced the solubilisation of phosphate and potassium rocks applied directly into soil which contained low $\mathrm{P}$ and $\mathrm{K}$ nutrients. This serves as a viable alternative to soluble $\mathrm{P}$ and $\mathrm{K}$ fertiliser to improve growth, photosynthesis and yields of fruit, shoot and root of hot pepper. Synergistic effects of combined inoculation of PGPRs have also been reported in various crops, such as potatoes (Kundu and Gaur, 1980), rice (Tiwari et al., 1989) and sugar beet and barley (Çakmakçi et al., 1999). Growth enhancement by Bacillus may also be associated with its ability to produce hormones, especially IAA (Sheng and Huang, 2001), to produce siderophores (Hu and Boyer, 1996), and to suppress pathogenic bacteria (Zehnder et al., 2001; Anith et al., 2004). The increasing bioavailability of $\mathrm{P}$ and $\mathrm{K}$ in soils with inoculation of PGPR or with combined inoculation and rock material application has frequently been reported (Omer, 1998; Wahid and Mehana, 2000; Lin et al., 2002; Park et al., 2003; Anith et al., 2004), and may lead to increased $\mathrm{P}$ uptake and plant growth.

\section{2. $P$ and $K$ availability}

Applications of soluble fertiliser, complete PK rocks and PK-solubilising bacterial strains, and PK rocks consistently increased available $\mathrm{P}$ and $\mathrm{K}$ nutrients in the rhizosphere in 10 and 20 weeks over the control in both 2001 and 2002 (Tab. II). $P$ rock only increased available $P$ in the 10 weeks of the first year's application; K rock application increased K availability in both 10 and 20 weeks for the two years; whereas PK rocks increased both $\mathrm{P}$ and $\mathrm{K}$ availability during most of the 10 and 20 weeks in both years. Sole applications of PGPR (singly or in combination) did not affect the availability of $\mathrm{P}$ and $\mathrm{K}$ in the rhizosphere. When $\mathrm{P}$ rock was combined with inoculation of PK-solubilising bacteria and $\mathrm{K}$ rock with $\mathrm{K}$-solubilising bac- teria, the availability of $\mathrm{P}$ and $\mathrm{K}$ increased in the 10- and 20week observations for both years. This suggests that inoculated bacterial strains successfully compete with existing natural bacteria. Although competition with indigenous less-effective rhizobia has been extensively studied in rhizobial inoculation (Lopez-Gracia et al., 2002; Loh and Stacey, 2003), competition in PGPR inoculants has not been intensively explored, since some PGPR might also possess properties to suppress pathogenic bacteria (Zehnder et al., 2001; Anith et al., 2004). Bacterial inoculation, which can improve $\mathrm{P}$ and $\mathrm{K}$ availability in soils by producing organic acids and other chemicals, stimulated growth and mineral uptake of plants (Alexander, 1977; Park et al., 2003). Our experiment demonstrated that the synergistic effects of co-inoculation of PK-solubilising bacteria integrated with the direct application of PK rocks was not different with regards to $\mathrm{P}$ and $\mathrm{K}$ availability in plots treated with industrial fertiliser.

\subsection{Acid phosphatase activity}

Acid phosphatase activities in 20 weeks were consistently higher than those in 10 weeks in both 2001 and 2002, but no difference was observed in the activities between the two years (Fig. 4). The highest phosphate activities occurred under soluble fertiliser, PK rocks and PK-solubilising bacteria and the combination of $\mathrm{P}$ rock and $\mathrm{P}$-solubilising bacteria, which were greater than those under the control $(P<0.05)$. Similar increases in acid phosphatase activity have also been reported in soils following inoculation with B. megaterium (Yao et al., 2002), and with the bacteria B. brevis, B. polymyxa and Xanthononas maltophilia (de Freitas et al., 1997), as well as with mycorrhizae (Fries et al., 1998; Jonathan et al., 2003) and earthworms (Wan and Wong, 2004). 
Table III. Effects of PK rocks and PK-solubilising bacteria on nutrient uptake of shoot, root and fruit of hot pepper in the 2001 and 2002 growing seasons. $\mathrm{LSD}_{0.05}=$ least significant difference at probability level of $5 \%$; $\mathrm{SF}=$ soluble fertiliser; $\mathrm{RP}=$ rock phosphate powder; $\mathrm{RK}=$ rock potassium powder; $\mathrm{PSB}=$ phosphate-solubilising bacteria; $\mathrm{KSB}=$ potassium-solubilising bacteria.

\begin{tabular}{|c|c|c|c|c|c|c|c|c|c|c|c|c|}
\hline \multirow[t]{2}{*}{ Treatment } & \multicolumn{3}{|c|}{ Shoot $\left(\mathrm{kg} \mathrm{ha}^{-1}\right)$} & \multicolumn{3}{|c|}{$\operatorname{Root}\left(\mathrm{kg} \mathrm{ha}^{-1}\right)$} & \multicolumn{3}{|c|}{ Fruit $\left(\mathrm{kg} \mathrm{ha}^{-1}\right)$} & \multicolumn{3}{|c|}{ Total $\left(\mathrm{kg} \mathrm{ha}^{-1}\right)$} \\
\hline & $\mathrm{N}$ & $\mathrm{P}$ & K & $\mathrm{N}$ & $P$ & $\mathrm{~K}$ & $\mathrm{~N}$ & $\mathrm{P}$ & $\mathrm{K}$ & $\mathrm{N}$ & $\mathrm{P}$ & $\mathrm{K}$ \\
\hline \multicolumn{13}{|l|}{2001} \\
\hline Control & 135.5 & 13.4 & 187.2 & 11.9 & 1.4 & 16.5 & 28.5 & 4.7 & 15.8 & 175.9 & 19.5 & 219.5 \\
\hline SF & 177.2 & 20.4 & 272.8 & 13.9 & 2.2 & 29.8 & 39.6 & 5.8 & 21.1 & 230.7 & 28.4 & 323.7 \\
\hline $\mathrm{RP}$ & 155.3 & 16.2 & 231.2 & 13.2 & 1.8 & 23.4 & 34.5 & 5.7 & 19.3 & 203.0 & 23.7 & 273.9 \\
\hline RK & 142.7 & 14.4 & 225.0 & 12.0 & 1.5 & 26.3 & 32.5 & 5.0 & 19.7 & 187.2 & 20.9 & 271.0 \\
\hline $\mathrm{RP}+\mathrm{RK}$ & 157.9 & 17.3 & 260.8 & 14.1 & 2.0 & 28.1 & 36.2 & 5.8 & 21.7 & 208.2 & 25.1 & 310.6 \\
\hline PSB & 138.5 & 14.5 & 198.0 & 12.2 & 1.5 & 18.9 & 29.9 & 4.8 & 16.8 & 180.6 & 20.8 & 233.7 \\
\hline KSB & 134.3 & 13.5 & 205.7 & 11.4 & 1.4 & 17.8 & 29.5 & 4.7 & 16.6 & 175.2 & 19.6 & 240.1 \\
\hline $\mathrm{PSB}+\mathrm{KSB}$ & 144.7 & 15.1 & 221.3 & 12.9 & 1.6 & 20.4 & 30.9 & 4.9 & 17.0 & 188.5 & 21.6 & 258.7 \\
\hline $\mathrm{RP}+\mathrm{PSB}$ & 166.4 & 18.4 & 250.8 & 14.3 & 2.0 & 24.3 & 38.2 & 6.0 & 22.4 & 218.9 & 26.4 & 297.5 \\
\hline $\mathrm{RK}+\mathrm{KSB}$ & 156.3 & 16.6 & 249.5 & 13.4 & 1.8 & 28.5 & 36.6 & 5.1 & 23.0 & 206.3 & 23.5 & 301.0 \\
\hline $\mathrm{RP}+\mathrm{RK}+\mathrm{PSB}+\mathrm{KSB}$ & 170.5 & 19.1 & 301.3 & 14.5 & 2.1 & 30.5 & 40.0 & 6.2 & 24.1 & 225.0 & 27.4 & 355.9 \\
\hline $\mathrm{LSD}_{0.05}$ & 29.1 & 2.5 & 60.9 & 2.0 & 0.4 & 9.1 & 7.7 & 1.0 & 4.8 & 32.0 & 4.1 & 74.6 \\
\hline \multicolumn{13}{|l|}{2002} \\
\hline Control & 139.0 & 14.0 & 177.7 & 11.3 & 1.5 & 20.3 & 30.6 & 4.5 & 17.2 & 180.9 & 20.0 & 215.2 \\
\hline SF & 182.8 & 22.1 & 284.1 & 13.6 & 2.0 & 32.8 & 39.4 & 6.0 & 23.0 & 235.8 & 30.1 & 339.9 \\
\hline $\mathrm{RP}$ & 156.2 & 17.5 & 224.7 & 12.4 & 1.8 & 24.5 & 36.4 & 5.4 & 20.8 & 205.0 & 24.7 & 270.0 \\
\hline RK & 138.2 & 15.2 & 230.7 & 11.8 & 1.7 & 30.5 & 33.5 & 5.1 & 20.6 & 183.5 & 22.0 & 281.8 \\
\hline $\mathrm{RP}+\mathrm{RK}$ & 159.5 & 17.6 & 268.4 & 13.0 & 2.0 & 33.4 & 37.7 & 5.8 & 22.5 & 210.2 & 25.4 & 324.3 \\
\hline PSB & 141.4 & 14.8 & 188.8 & 11.6 & 1.6 & 19.4 & 32.6 & 4.7 & 17.7 & 185.6 & 21.1 & 225.9 \\
\hline KSB & 135.8 & 13.6 & 185.6 & 10.7 & 1.5 & 20.0 & 28.9 & 4.3 & 16.5 & 175.4 & 19.4 & 222.1 \\
\hline $\mathrm{PSB}+\mathrm{KSB}$ & 147.0 & 15.6 & 209.4 & 12.2 & 1.7 & 21.7 & 33.3 & 4.9 & 18.5 & 192.5 & 22.2 & 249.6 \\
\hline $\mathrm{RP}+\mathrm{PSB}$ & 173.0 & 20.1 & 255.5 & 13.3 & 2.2 & 25.7 & 38.3 & 5.8 & 23.6 & 224.6 & 28.1 & 304.8 \\
\hline $\mathrm{RK}+\mathrm{KSB}$ & 163.5 & 17.0 & 276.9 & 12.3 & 1.7 & 32.4 & 35.8 & 5.6 & 24.5 & 211.6 & 24.3 & 333.8 \\
\hline $\mathrm{RP}+\mathrm{RK}+\mathrm{PSB}+\mathrm{KSB}$ & 178.3 & 20.3 & 284.4 & 13.8 & 2.4 & 38.2 & 40.2 & 6.2 & 26.3 & 232.3 & 28.9 & 348.9 \\
\hline $\mathrm{LSD}_{0.05}$ & 16.0 & 3.5 & 85.3 & 1.6 & 0.4 & 10.0 & 6.9 & 1.3 & 5.1 & 40.5 & 5.3 & 60.2 \\
\hline
\end{tabular}

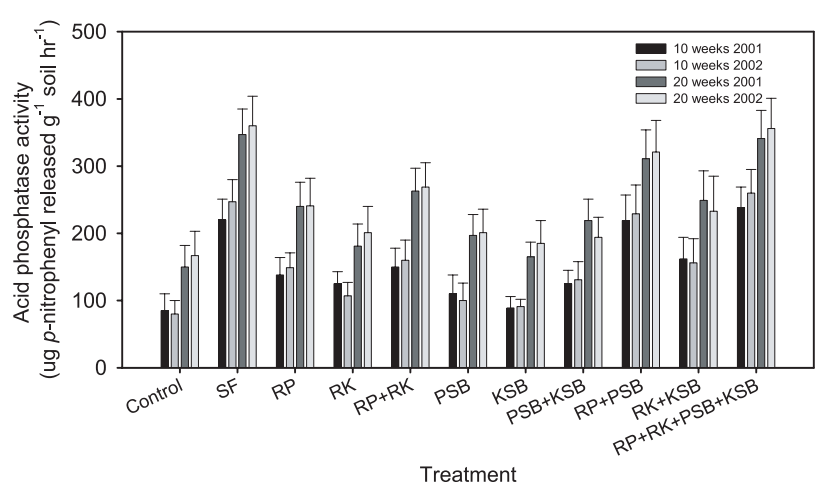

Figure 4. Effects of PK rock powder and PK-solubilising bacterial strains on acid phosphatase activity of hot pepper during the two growing seasons of 2001 and 2002. Means are shown \pm standard error $(\mathrm{n}=4) . \mathrm{SF}=$ soluble fertiliser; $\mathrm{RP}=$ rock phosphate powder; $\mathrm{RK}=$ rock potassium powder; $\mathrm{PSB}=$ phosphate-solubilising bacteria; $\mathrm{KSB}$ $=$ potassium-solubilising bacteria. The combination of PK rocks and PK-solubilising bacterial strains, and combination of $\mathrm{P}$ rocks and $\mathrm{P}$ solubilising bacteria resulted in a similar phosphatase activity to the application of soluble fertiliser; both of them produced phosphatase activity 2.5 and 2.6 times higher, respectively, as compared with control.

\subsection{Nutrient uptake}

Total N, P and K uptakes by shoot, root and fruit of hot pepper were consistently increased $(P<0.05)$ by soluble fertiliser and by the complete combination of PK rocks and PK-solubilising bacteria, and almost as consistently increased $(P<0.05)$ by the combination of $\mathrm{P}$ rock and $\mathrm{P}$-solubilising bacteria and by the combination of $\mathrm{K}$ rock and $\mathrm{K}$-solubilising bacteria in both 2001 and 2002 (Tab. III). The exception was the lack of effect on total $\mathrm{N}$ uptake by PK rocks and P rock and P-solubilising bacteria in 2002. In the two-year average, increases in total $\mathrm{N}$ uptake were as high as $31 \%$ in soluble fertiliser and $28 \%$ in the complete combination treatment over the control $(178 \mathrm{~kg}$ $\mathrm{N}$ uptake $\mathrm{ha}^{-1}$ ); in the case of $\mathrm{P}$ uptake, the highest average increases were $47 \%$ in soluble fertiliser and $43 \%$ in the complete treatment higher over $19.8 \mathrm{~kg} \mathrm{P} \mathrm{ha}^{-1}$ in the control; whereas, in the case of $\mathrm{K}$ uptake, $52 \%$ in soluble fertiliser and $62 \%$ higher over $217 \mathrm{~kg} \mathrm{~K} \mathrm{ha}^{-1}$ in the control (Tab. III). N, P and $\mathrm{K}$ uptake in shoot, root and fruit organs demonstrated similar patterns to those of the total N, P and K uptake, respectively.

The co-inoculation of PK-solubilising bacterial strains synergistically solubilised the PK rock powder added to the soil, 
which contained low $\mathrm{P}$ and $\mathrm{K}$ nutrients, converting them into forms much more available for uptake by plant roots. Higher $\mathrm{N}, \mathrm{P}$ and $\mathrm{K}$ uptake may subsequently promote photosynthetic activity and plant growth. Increasing $\mathrm{N}$ uptake in our experiment with inoculation with Bacillus may be related to the fact that Bradyrhizobium sp., a genus which fixes atmospheric nitrogen in symbiosis with legumes, is phylogenically closer to Bacillus than to other rhizobial genera (Zakhia and de Lajudie, 2001; Anith et al., 2004). Therefore, the Bacillus strain used in this study might have the capacity to fix atmospheric nitrogen. It is known that $\mathrm{P}$ availability in soils is also important for the uptake of $\mathrm{N}$ from soils and its utilisation in plants (Kim et al., 2003). Therefore, it is also possible that more available $\mathrm{P}$, due to solubilisation by the inoculated PSB, may cause the enhancement of $\mathrm{N}$ uptake.

\section{CONCLUSION}

Biofertilisers have been used as sources to improve plant nutrients in sustainable agriculture. Our experiments were conducted to evaluate the effects of soil fertilisation with PK rocks and co-inoculation with PK-solubilising bacteria on the improvement of $\mathrm{P}$ and $\mathrm{K}$ uptake and the growth and production of hot pepper plants. The results demonstrated that there is mostly no difference in $\mathrm{N}, \mathrm{P}$ and $\mathrm{K}$ mineral availability and uptake, plant photosynthesis, plant dry matter, and fruit yield between application of soluble fertiliser and the complete integration of PK rocks and PK-solubilising bacteria. This suggests that the use of rocks containing phosphate and potassium combined with the co-inoculation of PK-solubilising bacterial strains in soil with low fertility provides a sustainable alternative to the use of industrial fertilisers for hot pepper production.

\section{REFERENCES}

Alexander M. (1977) Introduction to soil microbiology, John Wiley and Sons Inc., New York, USA.

Allison L.E. (1965) Organic carbon, in: Black C.A. (Eds.), Methods of soil analysis, Am. Soc. Agron. Inc. Publ., Madison, USA, pp. 13671376.

Anith K.N., Momol M.T., Kloepper J.W., Marois J.J., Olson S.M., Jones J.B. (2004) Efficacy of plant growth-promoting rhizobacteria, acibenzolar- $S$-methyl, and soil amendment for integrated management of bacterial wilt on tomato, Plant Dis. 88, 669-673.

Bhuvaneswari T.V., Turgeon B.G., Bauer W.D. (1980) Early events in the infection of soybean (Glycine max L. Merr.) by Rhizobium japonicum I. location of infectable root cells, Plant Physiol. 66, 1027-1031.

Bojinova D., Velkova R., Grancharov I., Zhelev S. (1997) The bioconversion of tunisian phosphorite using Aspergillus niger, Nutr. Cyc. Agroecosys. 47, 227-232.

Brady N.C. (1990) The nature and properties of soils, Macmillan, New York, USA, pp. 351-380.

Brown L.R. (2000) Fertiliser use down, in: Brown L.R., Renner M., Halweil B. (Eds.), The environmental trends that are shaping our future, Earthscan, London, UK, pp. 46-47.

Bremner J.M. (1965) Total Nitrogen, in: Methods of Soil Analysis, Part 2, Black C.A. (Eds.), ASA Madison, WI, USA, pp. 1149-1176.
Çakmakçi R., Kantar F., Algur Ö.F. (1999) Sugar beet and barley yields in relation to Bacillus polymyxa and Bacillus megaterium var. phosphaticum inoculation, J. Plant Nutr. Soil Sc. 162, 437-442.

de Freitas J.R., Banerjee M.R., Germida J.J. (1997) Phosphate-solubilising rhizobacteria enhance the growth and yield but not phosphorus uptake of canola (Brassica napus L.), Biol. Fert. Soils 24, 358-364.

Friedrich S., Platonova N.P., Karavaiko G.I., Stichel E., Glombitza F. (1991) Chemical and microbiological solubilization of silicates, Acta Biotechnol. 11, 187-196.

Fries L.L., Pacovsky R.S., Safir G.R., Kaminski J. (1998) Phosphorus effect on phosphatase activity in endomycorrhizal maize, Physiol. Plantarum 103, 162-171.

Gerke L. (1992) Phosphate, aluminum, and iron in the soil solution of three different soils in relation to varying concentrations of citric acid, Z. Pflanzenernahr. Bodenk. 155, 17-22.

Han H.S., Supanjani, Lee K.D. (2006) Effect of co-inoculation with phosphate and potassium solubilizing bacteria on mineral uptake and growth of pepper and cucumber, Plant Soil Environ. 52, 130-136.

Hoagland D.R., Arnon D.I. (1950) A water culture method for growing plants without soil, Calif. Agric. Exp. Stat. Circular 347.

Hu X., Boyer G.L. (1996) Siderophore-mediated aluminum uptake by Bacillus megaterium ATCC 19213, Appl. Environ. Microb. 62, 4044-4048.

Illmer P., Barbato A., Schinner F. (1995) Solubilization of hardly-soluble $\mathrm{AlPO}_{4}$ with P-solubilizing microorganism, Soil Biol. Biochem. 27, 265-270.

Jonathan R. Cumming, Ning J. (2003) Arbuscular mycorrhizal fungi enhance aluminium resistance of broomsedge (Andropogon virginicus L.), J. Exp. Bot. 54, 1447-1459.

Kim T., Jung W., Lee B., Yoneyama T., Kim H., Kim K. (2003) P effects on $\mathrm{N}$ uptake and remobilization during regrowth of Italian ryegrass (Lolium mutiflorum), Environ. Exp. Bot. 50, 233-242.

Kundu B.S., Gaur A.C. (1980) Effect of phosphobacteria on the yield and phosphate uptake of potato crop, Curr. Sci. 49, 159.

Lin Q.M., Rao Z.H., Sun Y.X., Yao J., Xing L.J. (2002) Identification and practical application of silicate-dissolving bacteria, Agr. Sc. China 1, 81-85.

Loh J., Stacey G. (2003) Nodulation gene regulation in Bradyrhizobium japonicum: a unique integration of global regulatory circuits, Appl. Environ. Biol. 69, 10-17.

Lopez-Garcia S.L., Vazquez T.E.E., Favelukes G., Lodeiro A.R. (2002) Rhizobial position as a main determinant in the problem of competition for nodulation in soybean, Environ. Microbiol. 4, 216-224.

Nahas E., Banzatto D.A., Assis L.C. (1990) Fluorapatite solubilization by Aapergillus niger in vinasse medium, Soil Biol. Biochem. 22, 1097-1101.

Omer S.A. (1998) The role of rock-phosphate-solubilizing fungi and vesicular arbuscular mycorrhiza (VAM) in growth of wheat plants fertilized with rock phosphate, World J. Microb. Biot. 14, 211-218.

Park M., Singvilay O., Seok Y., Chung J., Ahn K., Sa T. (2003) Effect of phosphate solubilizing fungi on $\mathrm{P}$ uptake and growth to tobacco in rock phosphate applied soil, Korean J. Soil Sci. Fert. 36, 233238.

Rajan S.S.S., Watkinson J.H., Sinclair A.G. (1996) Phosphate rock of for direct application to soils, Adv. Agron. 57, 77-159.

RDA (Rural Development Administration, Korea) (1988) Methods of soil chemical analysis, National Institute of Agricultural Science and Technology, RDA, Suwon, Korea.

RDA (Rural Development Administration, Korea) (1995) Standard investigation methods for agricultural experiment, National Institute of Agricultural Science and Technology, RDA, Suwon, Korea, p. 601 . 
Richards J.E., Bates T.E. (1989) Studies on the potassium-supplying capacities of southern Ontario soils. Measurement of available K, Can. J. Soil Sci. 69, 597-610.

Şahin F., Çakmakçi R., Kantar F. (2004) Sugar beet and barley yields in relation to inoculation with $\mathrm{N}_{2}$-fixing and phosphate solubilizing bacteria, Plant Soil 265, 123-129.

Sample E.C., Soper R.J., Racz G.J. (1980) Reactions of phosphate fertilisers in soils, in: Khasawneh F.E., Sample E.C., Kamprath E.J. (Eds.), The role of phosphorus in agricultures, Am. Soc. Agron., Madison, Wisconsin, USA, pp. 263-310.

Schilling G., Gransee A., Deubel A., Lezovic G., Ruppel S. (1998) Phosphorus availability, root exudates, and microbial activity in the rhizosphere, Z. Pflanzenernahr. Bodenkd. 161, 465-478.

Sheng X.F., He L.Y., Huang W.Y. (2002) The conditions of releasing potassium by a silicate-dissolving bacterial strain NBT, Agr. Sc. China 1, 662-666.

Sheng X.F., Huang W.Y. (2001) Physiological characteristics of strain NBT of silicate bacterium, Acta Pedologica Sinica 38, 569-574.

Sheng X.F., Huang W.Y. (2002) Mechanism of potassium release from feldspar affected by the strain NBT of silicate bacterium, Acta Pedologica Sinica 39, 863-871.

Sundara B., Natarajan V., Hari K. (2002) Influence of phosphorus solubilizing bacteria on the changes in soil available phosphorus and sugarcane and sugar yields, Field Crop. Res. 77, 43-49.

Tabatabai M.A. (1982) Soil enzymes, in: Page A.L., Miller R.H., Keeney D.R. (Eds.), Methods of soil analysis, Am. Soc. Agron., Madison, Wisconsin, USA, pp. 903-947.
Tiwari V.N., Lehri L.K., Pathak A.N. (1989) Effect of inoculation crops with phospho-microbes, Exp. Agr. 25, 47-50.

Ullman W.J., Kirchman D.L., Welch S.A. (1996) Laboratory evidence for microbially mediated silicate mineral dissolution in nature, Chem. Geol. 132, 11-17.

Vessey J.K. (2003) Plant growth promoting rhizobacteria as biofertilisers, Plant Soil 255, 571-586.

Vincent J.M. (1970) A manual for the practical study of the root-nodule bacteria, Burgess and Son Ltd., Great Britain, p. 45.

Wahid O.A., Mehana T.A. (2000) Impact of phosphate-solubilizing fungi on the yield and phosphorus uptake by wheat and faba bean plants, Microbiol. Res. 155, 221-227.

Wan J.H.C., Wong M.H. (2004) Effects of earthworm activity and P-solubilizing bacteria on P availability in soil, J. Plant Nutr. Soil Sc. 167, 209-213.

Xie J.C. (1998) Present situation and prospects for the world's fertiliser use, Plant Nutr. Fer. Sci. 4, 321-330.

Yao Q., Qing F.L., Li X.L., Christie P. (2002) Utilization of sparingly soluble phosphate by red clover in association with Glomus mosseae and Bacillus megaterium, Pedosphere 12, 131-138.

Zehnder G.W., Murphy J.F., Sikora E., Kloepper J.W. (2001) Application of rhizobacteria for induced resistance, Eur. J. Plant Pathol. 107, 39-50.

Zakhia F., de Lajudie P. (2001) Taxonomy of rhizobia, Agronomie 21, 569-576.

To access this journal online: www.edpsciences.org 